\title{
PERBEDAAN PENGARUH ASUPAN KACANG TANAH (Arachis hypogaea) REBUS DAN PANGGANG TERHADAP KADAR ASAM URAT DALAM DARAH PADA WANITA DISLIPIDEMIA
}

\author{
Fransiska Angelina, Kusmiyati DK ${ }^{*}$, Yekti Wirawanni*) \\ Program Studi Ilmu Gizi Fakultas Kedokteran Universitas Diponegoro \\ Jl.Dr.Sutomo No.18, Semarang, Telp (024) 8453708, Email : gizifk@ undip.ac.id
}

\begin{abstract}
ABSTRAK
LatarBelakang : Hiperurisemi dipengaruhi oleh keadaan dislipidemia dan asupan purin. Kondisi dislipidemia mengakibatkan menurunnya aktivitas enzim GA3PDH (Glyceraldehyde 3 phospate dehydrogenase) yang menyebabkan terjadinya diversi ribose-5-phospate menjadi PRPP (phosphoribosyl pyrophosphate). PRPP lalu ditransformasi menjadi inosine monophosphate (IMP). Dari senyawa perantara yang berasal dari adenosine monophosphate (AMP) dan guanosine monophosphate (GMP), purinic nucleotides digunakan untuk sintesis DNA dan RNA, dilanjutkan dengan inosinyang kemudian akan mengalami degradasi menjadi hipoxantin, xantindan akhirnya menjadiasam urat. Asupan purin yang berlebihan seperti kacang tanah juga dapat meningkatkan kadar asam urat darah. Penelitianinibertujuanuntukmengetahuiperbedaan pengaruhasupan kacang tanah rebus dan panggang pada wanita dislipidemia.

Metode : Jenis penelitian adalah true experiment dengan rancangan pre test - post test. Subjek adalah 22 wanita dislipidemia dengan kadar kolesterol $L D L \geq 130 \mathrm{mg} / \mathrm{dl}$, HDL $\leq 40 \mathrm{mg} /$ dl dan kadar asam urat normal 2,4-6,1 mg/dl. Subjek dibagi menjadi 2 kelompok dengan metode simple randomization, yang terdiri atas kelompok perlakuan pertama dan kelompok perlakuan kedua, masing-masing kelompok terdiri dari 11 subjek. Kelompok perlakuan pertama mendapatkan kacang tanah rebus sebanyak 77 gram/hari dan kelompok perlakuan kedua mendapatkan kacang tanah panggang sebanyak 77 gram/hari. Pemberian kacang tanah rebus dan panggang dilakukan selama 4 minggu. Uji normalitas menggunakan Shapiro Wilk. Analisis statistik menggunakan uji dependent $t$-test dan independent $t$-test.

Hasil : Rerata kadar asam urat sebelum intervensi pada kelompok rebus yaitu 3,94 mg/dl dan pada kelompok panggang 4,45mg/dl. Rerata kadar asam urat setelah intervensi pada kelompok rebus yaitu 4,79 mg/dl dan pada kelompok panggang 4,41 $\mathrm{mg} / \mathrm{dl}$. Ada perubahan rerata kadar asam urat darah setelah diberikan kacang rebus $(p=0,002)$. Tidak ada perubahan rerata kadar asam urat darah setelah diberikan kacang panggang $(p=0,851)$.

Kesimpulan : Ada perbedaan pengaruh konsumsi kacang tanah rebus dan panggang terhadap kadar asam urat darah pada wanita dislipidemia. Ada perubahan rerata kadar asam urat darah setelah diberikan kacang tanah rebus $(p=0,002)$.
\end{abstract}

Kata kunci : asam urat; dislipidemia; kacang tanah

\begin{abstract}
Background : Hyperuricemia are affected by the state of dyslipidemia and purine intake. Dyslipidemia itself could cause an enzyme called GA3PDH (Glyceraldehyde 3 phospate dehydrogenase) activities goes declining, which can cause diversion-5-phospate into PRPP (phosporibosyl pyrophosphate). PRPP than transformed into inosine monophosphate (IMP) from intermediate compound which came from adenosine monophosphate (AMP) and guanosine monophospate (GMP), purinic nucleotides being used for DNA and RNA synthesis, and then continued with inosine that will be degraded into hypoxantin, xantin and finally became uric acid. Excessive intake $f$ purine like peanuts could also increase uric acid levels in the blood. The aim of this study are to know the difference implication of boiled and roasted peanuts intake in women with dyslipidemia.

Methods : This research was true experiment with the design of pre-test - post test. Subjects were 22 dyslipidemic women with $L D L$ cholesterol levels $\geq 130 \mathrm{mg} / \mathrm{dl}$, $H D L \leq 40 \mathrm{mg} /$ dl and normal uric acid levels from 2.4 to $6.1 \mathrm{mg}$ / dl. Subjects were divided into 2 groups by simple randomization method, which consists of the first group and the second group, each group consists of 11 subjects. The first group consumed boiled peanuts as much as 77 grams / day and the second group consumed roasted peanuts as much as 77 grams / day. Boiled and roasted peanuts has been given for 4 weeks. Using the Shapiro Wilkfor normality test. Statistical analysis using a dependent t-test and independent t-test

Result : The mean of uric acid levels before the intervention on the group that given with boiled peanuts is $3.94 \mathrm{mg} /$ $d l$ and the group that given with roasted peanuts is $4.45 \mathrm{mg} / \mathrm{dl}$. The mean of uric acid levels after intervention in the boiled group is $4.79 \mathrm{mg} / \mathrm{dl}$ and in the roasted group is $4.41 \mathrm{mg} / \mathrm{dl}$. There are changes in mean uric acid levels in the blood after been given with boiled peanuts $(p=0.002)$. There is no changes in mean uric acid levels in blood after been given with roasted peanuts $(p=0.851)$.
\end{abstract}

${ }^{*}$ Penulis Penanggungjawab 
Conclusion : There are difference influences from the consumption of boiled and roasted peanuts on blood uric acid levels in women with dyslipidemia. There are changes in mean uric acid levels in the blood after consumption of boiled peanuts $(p=0.002)$.

Keyword :uric acid; dyslipidemia; peanuts

\section{PENDAHULUAN}

Asam urat merupakan hasil akhir metabolisme purin $^{1,2,3,4}$. Kadar asam urat dapat diketahui dengan pemeriksaan darah dan urin. Nilai rujukan kadar asam urat normal pada laki laki yaitu $3.4-7.0 \mathrm{mg} / \mathrm{dl}$ sedangkan pada wanita yaitu $2.4-6.1 \mathrm{mg} / \mathrm{dl}^{2,5}$. Asam urat darah dalam kadar normal berperan sebagai antioksidan alami dengan cara melengkapi kekurangan elektron dan menghambat terjadinya reaksi berantai dari pembentukan radikal bebas yang dapat menimbulkan stress oksidatif ${ }^{2}$. Namun, kadar asam urat darah yang berlebihan dapat menyebabkan penumpukan asam urat yang disebut hiperurisemia ${ }^{6}$.

Prevalensi hiperurisemia di dunia cenderung mengalami peningkatan. Data National Health and Nutrition Examination Survey (NHANES III), menyebutkan prevalensi hiperurisemia pada orang dewasa di Amerika Serikat mengalami peningkatan selama lebih dari 10 tahun terakhir yaitu 2,7\% pada tahun 1994 dan menjadi $3,9 \%$ pada tahun $2008{ }^{7}$. Peningkatan prevalensi juga terjadi pada suku Aborigin Australia yaitu dari 0\% pada tahun 1965 menjadi $9,7 \%$ pria dan $2,9 \%$ wanita pada tahun $2002^{8}$. Tahun 2007, prevalensi hiperurisemia di kota Zhojiang, Cina sebesar 24,32\% pada pria dan 3,37 pada wanita, tahun 2008 meningkat menjadi $31,89 \%$ pada pria dan $10,83 \%$ pada wanita . Prevalensi hiperurisemia dan gout di Indonesia tidak diketahui secara pasti. Survei epidemiologik tahun 1992 yang di lakukan di Bandungan, Jawa Tengah atas kerjasama WHO-COPCORD terhadap 4.683 sampel berusia antara $15-45$ tahun di dapatkan bahwa prevalensi hiperurisemia sebesar $24,3 \%$ pada laki-laki dan $11,7 \%$ pada wanita ${ }^{10}$. Laporan dari puskesmas sekota Semarang tahun 2011 angka kejadian gout di kota Semarang sejumlah 1091 orang $^{11}$.

Hiperurisemi dipengaruhi oleh keadaan dislipidemia. Dislipidemia adalah suatu keadaan patologis dimana kadar kolestrol total $\geq 240 \mathrm{mg} / \mathrm{dl}$, LDL $\geq 130 \mathrm{mg} / \mathrm{dl}$, HDL $\leq 40 \mathrm{mg} / \mathrm{dl}$, dan Trigliserida $\geq 200 \mathrm{mg} / \mathrm{dl}^{23.24,25}$. Kondisi dislipidemia mengakibatkan menurunnya aktivitas enzim GA3PDH (Glyceraldehyde 3 phospate dehydrogenase) yang menyebabkan terjadinya diversi ribose-5-phospate menjadi PRPP (phosphoribosyl pyrophosphate). PRPP lalu ditransformasi menjadi inosine monophosphate $(I M P)$. Senyawa perantara yang berasal dari adenosine monophosphate (AMP) dan guanosine monophosphate (GMP), purinic nucleotides digunakan untuk sintesis DNA dan RNA, dilanjutkan dengan inosin yang kemudian akan mengalami degradasi menjadi hipoxantin, xantin dan akhirnya menjadi asam urat ${ }^{47}$.

Faktor yang mempengaruhi peningkatan kadar asam urat darah diantaranya tingginya asupan purin. Purin banyak terdapat pada makanan hewani maupun nabati seperti daging, jerohan, seafood, sayur bayam, biji-bijian dan kacangkacangan ${ }^{14}$ Kacang tanah sebagai sumber purin merupakan bahan makanan yang mudah didapatkan di Indonesia. Kacang tanah sering dikonsumsi oleh masyarakat dalam berbagai proses pemasakan seperti direbus, dipanggang, dan digoreng ${ }^{15}$. Kandungan purin kacang tanah termasuk kategori sedang yaitu sebesar 108 $\mathrm{mg} / 100 \mathrm{gr}$, sehingga konsumsi kacang tanah perlu diperhatikan agar tidak terjadi peningkatan kadar asam urat darah ${ }^{16}$

Penelitian yang dilakukan pada 54 orang laki-laki penderita hiperkolesterolemia, diberikan kacang tanah yang diproses dengan cara dipanggang sebanyak 77 gram selama 4 minggu. Berdasarkan penelitian tersebut diketahui bahwa terjadi terjadi penurunan kadar kolesterol LDL dan peningkatan kadar kolesterol $\mathrm{HDL}^{19}$. Penelitian tersebut hanya meneliti tentang pengaruh pemberian kacang tanah dengan proses yang dipanggang terhadap profil lipid pada laki-laki hiperkolesterolemia, namun penelitian tentang perbedaan pengaruh asupan kacang tanah rebus dan panggang terhadap kadar asam urat darah pada wanita dislipidemia belum ada. Kondisi wanita dislipidemia diikuti dengan mengkonsumsi kacang sebagai sumber purin dapat berisiko hiperurisemia. Hal tersebut mendorong peneliti untuk melakukan penelitian tentang pengaruh asupan kacang tanah terhadap kadar asam urat darah. Penelitian ini bertujuan untuk mengetahui perbedaan pengaruh pemberian kacang tanah rebus dan panggang terhadap kadar asam urat dalam darah pada wanita dislipidemia. 


\section{METODE}

Penelitian ini merupakan penelitian true experiment dengan rancangan pre test - post design. Variabel terikat (dependent) dalam penelitian ini adalah kadar asam urat. Variabel bebas (independent) adalah pemberian kacang tanah rebus dan panggang dengan dosis 77 gram, sementara variabel perancu adalah usia dan jenis kelamin (telah dikendalikan).

Ethical Clearance adalah bentuk persetujuan bahwa secara etik penelitian ini dapat dilakukan pada manusia. Oleh karena penelitian ini bersifat eksperimental yaitu memberikan intervensi khusus pada kelompok perlakuan, sehingga penelitian ini mendapat persetujuan dari Komite Etik, Fakultas Kedokteran Universitas Diponegoro. Pengambilan data sampel termasuk pemeriksaan darah dilakukan setelah mendapat persetujuan dari subjek dengan mengisi informed consent. Keterangan tentang untung dan ruginya mengikuti penelitian, serta efek samping dari intervensi dijelaskan kepada subjek oleh peneliti. Semua informasi dan data dari penelitian ini hanya dipakai untuk keperluan ilmiah dan kode maupun identitas subjek sangat dirahasiakan untuk umum.

Subjek penelitian merupakan karyawati di Gedung Pandanaran dan Sekretariat Daerah Provinsi Jawa Tengah Semarang. Kriteria inklusi penelitian ini adalah memiliki kadar kolesterol LDL $\geq 130 \mathrm{mg} / \mathrm{dl}$, kadar kolestrol $\mathrm{HDL} \geq 40 \mathrm{mg} / \mathrm{dl}$, kadar asam urat darah $2.4-6.1 \mathrm{mg} / \mathrm{dl}$, belum mengalami menopause, tidak sedang mengonsumsi obat penurun asam urat selama penelitian, tidak memiliki alergi terhadap kacang tanah.

Perhitungan subjek penelitian menggunakan rumus uji hipotesis terhadap rerata dua populasi independen dan dibutuhkan sebanyak minimal 10 subjek tiap kelompok. Penentuan subjek penelitian menggunakan metode consecutive sampling. Sebanyak 50 orang bersedia diambil darahnya untuk proses skrining awal dan diperoleh sebanyak 22 orang yang memenuhi kriteria inklusi. Pengambilan darah dilakukan oleh petugas laboratorium dari Laboratorium Permata Semarang. Subjek dibagi menjadi 2 kelompok dengan metode simple randomization, yang terdiri atas kelompok perlakuan pertama dan kelompok perlakuan kedua, masing-masing kelompok terdiri dari 11 subjek. Kelompok perlakuan pertama mendapatkan kacang tanah rebus sebanyak 77 gram/hari dan kelompok perlakuan kedua mendapatkan kacang tanah panggang sebanyak 77 gram/hari

Pemberian kacang tanah rebus dan panggang dilakukan selama 4 minggu. Asupan makan sehari-hari, pada kedua kelompok perlakuan tidak dikontrol. Pencatatan makan dilakukan sebelum dan selama intervensi dengan metode food recall 24 jam. Kepatuhan subjek mengonsumsi kacang tanah rebus dan panggang dicatat dengan menggunakan formulir daya terima. Pada kelompok perlakuan rebus, terdapat dua orang tidak menghabiskan kacang selama dua hari dan kelompok panggang terdapat satu orang tidak menghabiskan kacang selama 1 hari serta satu orang kelompok panggang menyisakan 25\% kacang selama 2 hari.

Kadar asam urat dianalisis dengan pemeriksaan laboratorium. Sampel darah diambil oleh petugas laboratorium setelah subjek berpuasa selama \pm 10 jam. Data asupan makan subjek dianalisis menggunakan program nutrisurvey.

Untuk menguji kenormalan data menggunakan uji Shapiro-Wilk. Perbedaan kadar asam urat darah sebelum dan sesudah intervensi menggunakan paired t-test karena data berdistribusi normal. Perbedaan pengaruh perlakuan kedua kelompok dianalisis dengan menggunakan uji independent t-test karena data berdistribusi normal.

\section{HASIL PENELITIAN \\ Karakteristik Subjek}

Karakteristik subjek yang terdiri dari gambaran umur, status gizi, dan asam urat awal digunakan untuk mendeskripsikan subjek penelitian secara jelas, terperinci, dan sistematis. Karakteristik subjek penelitian disajikan dalam tabel 1.

Tabel 1. Karakteristik subjek

\begin{tabular}{|c|c|c|c|c|c|c|c|}
\hline \multirow{2}{*}{ Variabel } & \multicolumn{4}{|c|}{$\begin{array}{l}\text { Rebus } \\
(n=11)\end{array}$} & \multicolumn{2}{|c|}{$\begin{array}{c}\text { Panggang } \\
(n=11)\end{array}$} & \multirow{2}{*}{$\mathbf{p}$} \\
\hline & Mean \pm SD & $\mathrm{n}$ & $\%$ & Mean \pm SD & $\mathrm{n}$ & $\%$ & \\
\hline $\begin{array}{l}\text { Umur } \\
\text { 30-39 }\end{array}$ & $42,89 \pm 6,02$ & 3 & $13,6 \%$ & $47,13 \pm 4,42$ & 1 & $4,5 \%$ & $0,076^{*}$ \\
\hline
\end{tabular}




\begin{tabular}{|c|c|c|c|c|c|c|c|}
\hline \multirow[b]{2}{*}{$40-49$} & & \multirow{3}{*}{$\begin{array}{l}8 \\
0\end{array}$} & \multirow[b]{2}{*}{$36,4 \%$} & & \multirow{2}{*}{\multicolumn{2}{|c|}{$31.8 \%$}} & \\
\hline & & & & & & & \\
\hline $50-59$ & & & $0 \%$ & & 3 & $13,6 \%$ & \\
\hline \multicolumn{8}{|l|}{ Status Gizi } \\
\hline Normal $(18,5-22,9$ kg/m²) & & 1 & $4,8 \%$ & & 3 & $14,3 \%$ & \\
\hline Overweight $(23-24,9$ & $27,08 \pm 3,28$ & 1 & $4,8 \%$ & $25,87 \pm 3,50$ & 3 & $14,3 \%$ & $0,210^{*}$ \\
\hline \multicolumn{8}{|l|}{$\left.\mathrm{kg} / \mathrm{m}^{2}\right)$} \\
\hline Obesitas (>25 kg/m²) & & 9 & $42,9 \%$ & & 5 & $23,8 \%$ & \\
\hline Asam urat awal & $3,94 \pm 1,15$ & & & $4,45 \pm 0,93$ & & & $0,269 *$ \\
\hline
\end{tabular}

*Uji beda independent $t$-test

Sebagian besar subjek dalam penelitian ini berada pada kelompok umur 40-49 tahun $(68,2 \%)$, sebagian besar memiliki kategori status gizi obesitas pada kelompok rebus $(42,9 \%)$ dan pada kelompok panggang $(23,8 \%)$. Hasil uji beda independent t-test menunjukkan tidak terdapat perbedaan umur dan status gizi antara kedua kelompok $(\mathrm{p}>0,05)$. Tidak terdapat perbedaan rerata kadar asam urat awal antara kelompok rebus dan panggang $(\mathrm{p}>0.05)$.

Pengaruh Konsumsi Kacang Tanah terhadap Kadar Asam Urat Darah

Tabel 2. Pengaruh konsumsi kacang tanah terhadap kadar asam urat darah

\begin{tabular}{lccc}
\hline \multirow{2}{*}{ Variabel } & Rebus $(\mathbf{n}=\mathbf{1 1})$ & Panggang $(\mathbf{n}=\mathbf{1 1})$ & \multirow{2}{*}{$\mathbf{p}^{\mathbf{1}}$} \\
\cline { 2 - 3 } & Mean \pm SD & Mean \pm SD & \\
\cline { 1 - 3 } Asam urat (mg/dl) & & & \\
Awal & $3,94 \pm 1,15$ & $4,45 \pm 0,93$ & \\
Akhir & $4,79 \pm 1,03$ & $4,41 \pm 0,56$ & 0,005 \\
$\boldsymbol{\Delta}$ & $0,84 \pm 0,67$ & $-0,03 \pm 0,62$ & \\
$\mathbf{P}$ & $0,002^{*}$ & $0,851^{*}$ & \\
\hline
\end{tabular}

*Uji dependent t-test

1 Uji beda Independent T-Test

Pada akhir penelitian didapatkan bahwa ada peningkatan kadar asam urat darah pada kelompok yang mengkonsumsi kacang rebus secara signifikan $(\mathrm{p}<0,05)$. Terjadi penurunan kadar asam urat darah pada kelompok yang diintervensi dengan kacang panggang tetapi tidak signifikan $(p>0,05)$
Perbedaan rerata perubahan kadar asam urat darah antar kedua kelompok dianalisis dengan uji Independent Samples T-Test, didapatkan bahwa ada perbedaan kadar asam urat dalam darah antara kelompok yang diintervensi dengan kacang rebus dan kacang panggang.

Asupan purin pada kelompok rebus dan panggang

Tabel 3 . Asupan purin pada kelompok rebus dan panggang

\begin{tabular}{lccc}
\hline \multirow{2}{*}{ Variabel } & Rebus $(\mathbf{n}=\mathbf{1 1})$ & Panggang $(\mathbf{n}=\mathbf{1 1})$ & \multirow{2}{*}{$\mathbf{p}^{\mathbf{1}}$} \\
\cline { 2 - 3 } & Mean \pm SD & Mean \pm SD & \\
Purin $(\mathbf{m g})$ & & & \\
Awal & $333,88 \pm 126,37$ & $282,26 \pm 109,81$ & 0,319 \\
Akhir & $299,96 \pm 63,25$ & $296,05 \pm 111,32$ & 0,920 \\
$\boldsymbol{\Delta}$ & $6,60 \pm 156,85$ & $13,79 \pm 140,84$ & 0,911 \\
$\mathbf{P}$ & $0,493 *$ & $0,752^{*}$ & \\
\hline
\end{tabular}

* paired t-test

1 Uji beda Independent T-Test

Tidak terdapat perbedaan rerata asupan purin sebelum dan selama intervensi baik pada kelompok rebus maupun kelompok panggang $(p>0.05)$. Tidak terdapat perbedaan kontrol asupan purin antara kelompok rebus dan kelompok panggang $(\mathrm{p}>0,05)$. 


\section{PEMBAHASAN}

Hasil penelitian sudah sesuai dengan hipotesis yaitu ada perbedaan pengaruh asupan kacang tanah rebus dan panggang terhadap kadar asam urat darah pada wanita dislipidemia.

Kadar asam urat dipengaruhi oleh usia dan jenis kelamin. Kadar asam urat semakin meningkat dimulai dari usia $>30$ tahun. Hal ini terjadi karena pada usia $>30$ tahun mulai terjadi proses penuaan. Proses penuaan mengakibatkan terjadinya penurunan organ tubuh secara fungsional sehingga terjadi gangguan homeostatis tubuh, seperti penurunan fungsi ginjal terhadap kecepatan filtrasi, ekskresi, dan reabsorbsi terhadap metabolisme asam urat ${ }^{12}$. Rata rata umur subjek pada penelitian ini adalah 42 tahun dengan rata rata kadar asam urat 3,94 mg/dl yang masih termasuk dalam kadar normal. Keadaan ini sudah sesuai dengan kriteria inklusi.

Kadar asam urat juga dipengaruhi oleh Body Mass Index (BMI). Risiko hiperurisemia meningkat jika BMI lebih dari $35 \mathrm{~kg} / \mathrm{m}^{2}$. Penelitian sebelumnya menyatakan adanya kaitan antara lemak omentum yaitu lemak yang menggantung di dalam rongga perut dengan hiperurisemia. Semakin besar volume lemak omentum, maka risiko hiperurisemia semakin tinggi. Lemak di bagian perut mendesak ginjal sehingga mengganggu fungsi ginjal dalam mengekskresikan kelebihan asam urat ${ }^{22,26}$. Sebagian besar sample pada penelitian ini berada dalam kategori status gizi obesitas pada kelompok rebus $(42,9 \%)$ dan pada kelompok panggang $(23,8 \%)$ sehingga berisiko hiperurisemia.

Kacang tanah mengandung basa purin adenin, hipoxantin, xantin, dan guanin yang dapat meningkatkan kadar asam urat darah. Kandungan basa purin pada kacang tanah yang paling memberikan pengaruh terhadap peningkatan kadar asam urat darah adalah basa purin adenin dan hipoxantin. Adenin dan hipoxantin sama sama meningkatkan kadar asam urat darah, tetapi hipoxantin memiliki efek lebih cepat menaikkan kadar asam urat darah dibandingkan dengan adenin 41,42 . Perbedaan kecepatan tersebut terjadi karena adanya perbedaan metabolisme pada masing masing basa purin, yaitu adenin harus mengalami fosforilisasi sebelum menjadi asam urat sedangkan hipoxantin tidak. Basa purin guanin dan xantin menunjukkan tidak memberikan pengaruh dalam peningkatan kadar asam urat darah ${ }^{42}$

Kelompok yang diintervensi dengan kacang rebus 77 gram/hari selama 4 minggu, menunjukkan adanya peningkatan kadar asam urat darah secara signifikan $(\mathrm{p}=0,002)$ yaitu dari 3,94 $\mathrm{mg} / \mathrm{dl}$ menjadi $4,79 \mathrm{mg} / \mathrm{dl}$. Hal ini terjadi karena pada kacang rebus terjadi penurunan kadar flavonoid. Penurunan kadar flavonoid disebabkan karena flavonoid bersifat larut air sehingga aktivitas enzim xanthin oxidase dalam mengubah xanthin menjadi asam urat tidak dihambat ${ }^{47}$.

Kelompok yang diintervensi dengan kacang panggang 77 gram/hari selama 4 minggu, menunjukkan adanya penurunan kadar asam urat darah tetapi tidak signifikan $(\mathrm{p}=0,851)$ yaitu dari $4,45 \mathrm{mg} / \mathrm{dl}$ menjadi $4,41 \mathrm{mg} / \mathrm{dl}$. Hal ini disebabkan karena adanya flavonoid pada kacang tanah yang dapat menghambat enzim xanthin oxidase sehingga menghambat xanthin dalam membentuk asam urat ${ }^{47}$.

Hasil penelitian ini ditemukan adanya perbedaan rerata perubahan kadar asam urat darah antar kelompok yang diintervensi dengan kacang rebus dan kacang panggang $(\mathrm{p}=0,005)$. Rerata perubahan kadar asam urat pada kelompok yang diintervensi dengan kacang rebus lebih tinggi daripada kelompok yang diintervensi dengan kacang panggang yaitu 4,79 mg/dl dan 4,41 mg/dl. Hal ini menunjukkan bahwa terdapat perbedaan kandungan flavonoid pada kacang tanah rebus dan panggang sehingga memberikan efek yang berbeda terhadap rerata perubahan kadar asam urat darah ${ }^{47}$.

Asupan purin selain kacang tanah yang diberikan diukur menggunakan recall 24 jam dengan tujuan untuk mengetahui asupan purin selain kacang tanah yang dikonsumsi subjek yang dapat mempengaruhi kadar asam urat darah. Hasil penelitian ini ditemukan bahwa tidak terdapat perbedaan rerata asupan purin sebelum dan selama intervensi baik pada kelompok rebus maupun kelompok panggang $(p>0.05)$ dan juga tidak terdapat perbedaan perubahan asupan purin antara kelompok rebus dan kelompok panggang $(\mathrm{p}>0,05)$. Maka dengan demikian dapat dikatakan bahwa asupan purin antar kedua kelompok tidak mempengaruhi perubahan kadar asam urat darah.

\section{KETERBATASAN PENELITIAN}

Keterbatasan penelitian ini adalah tidak dilakukan uji kandungan hipoxantin, adenin, guanin, xantin, dan flavonoid pada kacang tanah rebus dan panggang.

\section{KESIMPULAN}

Terdapat peningkatan kadar asam urat darah yang signifikan pada kelompok yang mengkonsumsi kacang rebus $(p<0,05)$. Terjadi penurunan kadar asam urat darah pada kelompok 
yang mengkonsumsi kacang panggang tetapi tidak signifikan $(p>0,05)$. Terdapat perbedaan kadar asam urat dalam darah antar kelompok yang mengkonsumsi kacang rebus dan kacang panggang $(\mathrm{p}<0,05)$.

\section{DAFTAR PUSTAKA}

1. Oda M, Satta Y, Takenaka O, Takahata N. Loss of Urate Oxidase Activity in Hominoids and Its Evolutionary Implications. Mol Bio Evol. 2002;19(5):640-653.

2. Ames BN, Cathcart R, Schwiers E, Hochstein P. Uric acid provides an antioxidant defense in humans against oxidant- and radical-caused aging and cancer: a hypothesis. Proc Natl Acad Sci U S A. 2000;78(11):6858-6862.

3. Putra Tjokarda R. Hiperurisemia. Dalam: Ilmu penyakit dalam jilid 2. Edisi 4. Jakarta: Departemen Ilmu Penyakit Dalam Fakultas Kedokteran Universitas Indonesia; 2006;p.2031206.

4. Burns DK, Kumar V. Sistem Muskuloskeletal. Dalam: Buku ajar patologi. Edisi 7. (alih bahasa: Brahm U Pendit). Jakarta: EGC; 2007.

5. Lin KC, Lin HY, Chou P. The Interaction Between Uric Acid Level and Other Risk Factors on The Development of Gout among Asymptomatic Hyperurisemic Men in A Prospective Study. J Rheumatol. 2000; 27:1501-1505.

6. Spieker EL, Ruschitzka TF, Luscher FT, Noll G. Altered Uric Acid Level and Disease States, The Journal of Pharmacology and Experimental Therapeutics.2007.

7. Zhu Y, Pandya BJ,Choi HK. Prevalence of Gout and Hyperuricemia in the US General Population. The National Health and Nutrition Examination Survey 2007-2008. Arthritis and Rheumatism, October 2011: 63(10): p3136-3141.

8. Robinson PC, Taylor WJ, Merriman TR. Systematic review of the prevalence of gout and hyperuricemia in Australia. Internal Medicine Journal, 2012.

9. Liu B, Wang T, Zhao HN, Yue WW, Yu HP, Liu $\mathrm{CX}$, et al. The prevalence of hyperuricemia in China: a meta-analysis. BMC Public Health 2011, 11:832.

10. Rumah Sakit Umum Kardinah, Profil Kesehatan Rumah Sakit, Tegal, 2008.

11. Dinas Kesehatan Jawa Tengah, Surveilans Penyakit Tidak Menular pada Puskesmas dan Rumah Sakit di Jawa Tengah. Semarang; 2007.

12. Yu KH., Luo SF. Younger Age of Onset of Gout in Taiwan. Rheumatol. 2003; 42:166-70.

13. Matsubara, Miyao, Chiba H, Marouka S, Katayose $S$, Elevated Serum Leptin Concentration in Women with Hyperuricemia, Journal of Atherosclerosis and Thrombosis, 2002, 9:28-34.
14. Hamdani SPG, Haman H, Susetyowati. High Consumption of Carbohydrate, Protein, Fat as Risk Factor of Dislipidemia in Lectures of Gadjah Mada University (GMU) Having Medical Check Up at GMC Health Center Yogyakarta. Program Faculty of Medicine Gadjah Mada University Yogyakarta. 2011.

15. Yvonne C, Walker L, Vogler B, Verghese M. Changes in the Phytochemical Comppisition and Profile of Raw, Boiled, and Roasted Peanuts. J. Agric Food Chem 2007;55:9266-9273.

16. Lingga, Lanny. Bebas Penyakit Asam Urat Tanpa Obat. Jakarta : Argomedia Pustaka, 2012; p.243245

17. Chukwumah Yvonne, L Walker L, Vogler B, Verghese M. Changes in the Phytochemical Comppisition and Profile of Raw, Boiled, and Roasted Peanuts. J. Agric Food Chem 2007; 55:9266-9273.

18. Eshak ES, Iso H, Date C, Kikuchi S, Watanabe Y, Wada Y, et al. Dietary fiber intake is Associated with Reduced Risk of Mortality from Cardiovascular Disease among Japanesse Men and Women. J.Nutr 2010. 140: 1445-1453.

19. Ghadimi N, Kimiagar M, Abadi A, Mirzazedah M, Harrison G. Peanut Consumption and Cardiovascular Risk. Public Health Nutrition: 13(10):1581-1586

20. Murray RK, Granner DK, Rodwell VW. Biokimia Harper edisi 27. (alih bahasa: dr. Brahm U. Pendit). Jakarta: Penerbit Buku Kedokteran EGC; 2006.

21. Sautin, Yuri Y, Richard J . Johnson, Uric Acid : The Oxidant- Antioxidant Paradox, Nucleosides, Nucleotids, Nucleic Acids, 2008, 27(6):608-619.

22. Lingga, Lanny. Bebas Penyakit Asam Urat Tanpa Obat. Jakarta : Argomedia Pustaka, 2012; p.243245

23. Janice R, Couch S. Medical Nutrition Therapy for Cardiovasculer Desease. In : L Kathleen Mahan, Sylvia Escott-Stump, editors. Krause's Food and Nutrition Therapy. $13^{\text {th }}$ edition. Philadelphia,USA - Saunders Elsivier; 2012.p.742;34.

24. Ebbert JO, Jensen M. Fat Depots, Free Fatty Acids, and Dyslipidemia. J.Nutr. 2013. 5:498-508.

25. Robins SJ, Asya Lyass, Justin PZ, Joseph MM, Ramachandran SV. Insulin Resistance and the Relationship of Dyslipidemia to Coronary Heart Desease : The Framingham Heart Study. Arterioscler Thromb Vasc Biol. 2011;31:12081214.

26. Akram M, Asif HM, Usmagram K, et al., Obesity and The Risk of Hyperuricemia in Gadap Town Karachi. African J. Of Biotechnology, 2011 ; 10(6), p.996-98.

27. Saag K, H Choi. Epidemiology, risk factors, and lifestyle modifications for gout. Arthritis Research \& Therapy 2006, 8(1):S2 
28. Ajibade VA, Famurewa O. Histopathological and Toxiocological Effect of Crude Saponin Extract from Phyllanthus Niruri, L (Syn.P. Franternus. Webster) on Organs in Animal Studies. Global Journal of Medical Research, Vol. 12 Issue 1 Version 1.0, 2012.

29. Hatano T, Yasuhara T, Yoshihara R, Agata I. Effect of Interaction of Tannis with Co-existing Substances. VII. Inhibitory Effect of Tannis and Related Polyphenol on Xanthine Oxidase. 38 (5) : 1224-9, 1990

30. Chen GL, Wei W, Xu SY. Effect and Mechanism of Total Saponin of Dioscorea on Animal Experimental Hyperuricemia. Am J Chin Med, 34(1) : 77-85, 2006.

31. Hatano T, Yasuhara T, Yoshihara R, Agata I. Effect of Interaction of Tannis with Co-existing Substances. VII. Inhibitory Effect of Tannis and Related Polyphenol on Xanthine Oxidase. 38 (5) : 1224-9, 1990.

32. Hamdani SPG, Haman H, Susetyowati. High Consumption of Carbohydrate, Protein, Fat as Risk Factor of Dislipidemia in Lectures of Gadjah Mada University (GMU) Having Medical Check Up at GMC Health Center Yogyakarta. Program Faculty of Medicine Gadjah Mada University Yogyakarta. 2011.

33. Bosiacka, Bawanowska, A.J. Hlynczak, B. Wiszniewska, M. Marchlewicz, Disorders of Purine Metabolism in Human Erythrocytes in the State of Lead Contamination, Polish Journal of Enviromental Studies Vol. 13, 2004, 5:467-476.

34. Choi HK, Atkinson K, Karlson EW, et al. Purinerich foods, dairy and protein intake, and the risk of gout in men. N Engl J Med 2004; 350:1093-103.

35. Choi HK, Liu S, Curhan G. Intake of purine-rich foods, proteins, and dairy products and relationship to serum levels of uric acid. Arthritis and Rheumatism 2005 Jan; 52(1): p.283-289.

36. Garrett R, Grisham, C. Nucleotides and Nucleic Acids. Biochemistry. 3rd ed. USA: Thomson Brooks/Cole. 2005. p 309-34.

37. Bendich A. Chemistry of Purines and Pyrimidines. In: Chargaff E, Davidson JN, editors. The Nucleic Acids Chemistry and Biology. New York, N.Y.: Academic Press Inc., Publishers.2005 p 81-125.

38. So, Alexander, Bernard Thorens, Uric Acid and Disease, The Journal of Clinical Investigation Vol.120, 2010.

39. Lyu LC, Hus, C.Y., Yeh, C.Y., Lee, M.S., Huang, S.H., Chen, C.L. A case-control study of the association of diet and obesity with gout in Taiwan. American Journal of Clinical Nutrition 2003. 78:690-701

40. Brule D, Sarwar G, Savoiet L. Purine content of selected canadian food products. Journal of Food Composition and Analysis 2008. 1(2):130-8.
41. Budavari S, editor. The Merck Index. Twelfth Edition ed. Whitehouse Station, NJ: Merck and Co., Inc. 2006

42. Clifford AJ, Riumallo, J.A., Young, V.R., Scrimshaw, N.S. Effects of oral purines on serum and urinary uric acid of normal, hyperuricaemic and gouty humans. . J Nutr 2006. 106:428-34.

43. Notoatmodjo S. Metodologi Penelitian Kesehatan. Jakarta : PT Rineka Cipta, 2012.

44. Madiyono B, Moeslichan S, Sastroasmoro S, Budiman I, Purwanto SH. Perkiraan Besar Sampel. Dalam : Sastroasmoro S, Ismael S, editor. Dasardasar Metodologi Penelitian Klinis. Edisi ke-3. Jakarta : CV. Sagung Seto; 2008.hal:302-311

45. Brule D, Sarwar G. Effects of Methods of Cooking on Free and Total Purine Bases. Canadian Institute of Food and Science Technology 1989. 22(3):248251.

46. Young. 1983. Effect of Stewing on Purine Content of Broiler Tissues. Journal of Food Science. 48:315

47. Yamamoto T, Moriwaki Y, Takahasi S. 2005. Effect of Ethanol on Metabolism of Purine Bases (hypoxanthine, xanthine, and uric acid). Journal of Endocrinology and Metabolism. 356 : 35-37 